\title{
Exploratory Studies, The Implementation Of Financial Technology In Micro, Small And Medium Enterprises (Msmes)
}

\author{
Murviana Koto ${ }^{1}$, Prawidya Hariani R. $\mathrm{S}^{2}$ and Baladhil Komala ${ }^{3}$ \\ \{murvianakoto@umsu.ac.id ${ }^{1}$ \} \\ ${ }^{1,2,3}$ University of Muhammadiyah Sumatera Utara, Jalan Kapten Mukhtar Barsi No. 3 Medan, North \\ Sumatra, Indonesia
}

\begin{abstract}
The development of information and communication technology has led to rapid changes in the social, economic and cultural fields. This research was conducted as an introduction to find out public perceptions in using technology-based financial products and services. This research was an exploratory study to find out how perceptions of economic actors, especially Micro, Small and Medium Enterprises (MSMEs) in obtaining loans and using technology-based payment transactions. The data source of this study was primary data, and the population in this study was MSMEs actors in Medan whose exact number was unknown. Accidental sampling was used to sampling technique, and from the distribution of data, 126 samples of MSMEs actors in Medan were obtained. The findings of this study illustrated that there were at least three main reasons for the lack of knowledge and willingness of MSMEs actors in Medan to use Fintech services. Firstly, people were still more secure, comfortable and confident to use credit services and financial transactions through banking services compared to Fintech. Secondly, there was still a lack of socialization given to the public regarding the existence of Fintech in Indonesia. Thirdly, the utilization of technological developments by Medanese people, especially MSMEs actors was still less optimal.
\end{abstract}

Keywords: Financial Technology, Micro, Small and Medium Enterprises

\section{Introduction}

The development of communication technology and information has caused rapid changes in the social, economic and cultural fields. The financial sector is also developing in a more efficient and modern direction. Basically, technology was used as a tool to support operational activities in the financial sector. However, as time went on, technology actually replaced the position of traditional financial services, thus facilitating access and time efficiency for users of financial services (Finansialku, 2018).

The use of technology in the financial world commonly referred to as financial technology or abbreviated as Fintech. Widespread use of the internet is a fundamental factor that drives the presence of Fintech. The survey of the Indonesian Internet Service Providers Association noted that the number of internet users has reached 132.7 million from a total of 256.2 million Indonesians (Asosiasi Penyelenggara Jasa Internet Indonesia, 2016) Internet use has changed people's behavior, including in trade. The process of buying and selling which was previously done face-to-face, is now shifting into an online buying and selling model commonly referred to as e-commerce. This encourages the growth of start-ups and businesses with innovative business models of new products and services. 
In Indonesia, most start-up companies are classified as Micro, Small and Medium Enterprises (MSMEs). At present, it is estimated that there are more than 140 start-up companies in Indonesia, and are predicted to continue to grow in line with the large untapped market potential (Rahardjo, 2017). The increase in this business model provides a substantial absorption of labors so that it is seen as making a significant contribution to the national economy. This makes the government give great attention such as by providing tax breaks.

The e-commerce model run by these MSMEs also makes the payment pattern shift. Buyers who do not meet the sellers directly also do not make direct payments. Traders and buyers also began to move to modern technology-based financial systems (technology base). This inevitably makes the financial industry have to innovate and change financial services that were once almost exclusively in the banking industry business (Chishti and Barberis, 2016).

Fintech deals with the construction of systems that make models and add value to various types of financial transactions. Fintech processes existing financial products and combines them with trading systems and technology to facilitate product purchase and sale transactions (Chishti and Barberis, 2016); (Freedman, 2006). Fintech is a new innovation in the field of financial services that aims to make it easier for society to access financial products, facilitate transactions, and improve financial literacy. Fintech is the use of technology in the financial system that will produce new products, services, technology and/or other business models. Fintech can have an impact on monetary stability, financial system stability, and / or efficiency, smoothness, security and reliability of the payment system. On the one hand, the development of financial technology can benefit consumers and business people, as well as the national economy, but on the other hand Fintech also has potential risks that can disrupt the financial system if it is not managed properly (Bank Indonesia, 2016).

As of June 2018, 63 financial technology companies have been registered and obtained official permission from the Indonesian Financial Services Authority (Financial Services Authority, 2018). In line with the growing number of Fintech companies and the increasing number of users, the services offered are also increasingly diverse. The payment system, financing or loans, investment in the capital market until packaged insurance are more attractive than those offered previously by banks. But this development also increases security risks in financial transactions (Rahardjo, 2017). The increasing risk along with the development of this technology requires a good understanding of financial literacy, because good financial literacy will help someone to be wiser in making financial decisions. Someone with a well financial literacy level will be more careful in making decisions to choose the financial product to be used, and will look for the source of information needed before, so that the decisions taken really take into account all the benefits and risks inherent (Koto and Pulungan, 2017); (Gunawan and Koto, 2017).

Based on this understanding, this research was conducted as an introduction to find out public perceptions of the use of Fintech. This study would investigate the perceptions of Micro, Small and Medium Enterprises (MSMEs) actors in Medan regarding credit services and payment transactions using Fintech.

\section{Literature Review}

McKinsey and Company's survey (2015) shows that since 2011 the adoption of digitalbanking services has increased rapidly throughout Asia. That is, many banking customers in Asia have switched to computers, smartphones and tablets in accessing services provided by banks. Customers prefer to make transactions online, rather than visiting banking offices. 
Particularly in developing countries in Asia, including Indonesia, the use of traditional channels such as through automatic teller machines (ATM) still dominates, but the use of the internet and smartphone-banking by customers has almost tripled compared to 2011 (Barquin and Shrikhande, 2018).

Miller (1992) showed that the main function of the financial system is to facilitate the allocation and dissemination of economic resources in uncertain environments. This function emphasizes the medium changing payment system, transferring resources from savers to investor-users, raising funds for time transformation purposes such as delaying consumption, and reducing risk through insurance and verified (Frame and White, 2002).

Literally, Financial Technology (Fintech) is defined as the use of technology that combines all technologies used in finance to facilitate trade, company business or interactions and services provided to retail consumers. The National Digital Research Center (NDRC) describes that Fintech is a term used to refer to an innovation in the field of financial services with a touch of modern technology, and is expected to bring a more practical process of financial transactions (Alimirruchi and Kiswara, 2017).

Fintech is an information technology-based financial service such as big data, cloud computing, and a distributed ledger system. Financial Technology is a technology and new innovation in the field of financial services with the aim of making it easier for people to access financial products, facilitate transactions, improve financial literacy, and replace traditional financial services to facilitate access and minimize public time in financial service problems (Martowardojo, 2016).

Bank Indonesia (BI) as the central bank in Indonesia divides Fintech into four categories of transactions based on the type of innovation, namely: (1). Payment, Clearing \& Settlement. This transaction provides payment system services organized by the banking industry and aims to simplify the process of online transactions. (2). Crowd funding and Peer to Peer Lending. This transaction is the implementation of financial services to bring lenders and loan recipients together in order to enter into an online lending and borrowing agreement. (3). Market Aggregate. This platform collects and processes various data so that it can provide certain information to online users. Through this information, users can choose products / services that match their needs and desires. (4) Investment \& Risk Management. This platform provides financial planning services in digital form. With online application services, users can make financial plans that are appropriate to their needs and abilities. This platform also teaches (Soediro, 2018); (Finansialku, 2018).

Based on the Law of the Republic of Indonesia Number 20 of 2008 concerning MSMEs, Micro-businesses are defined as productive businesses owned by individuals and / or individual business entities that meet the criteria of micro-enterprises as stipulated in the law. The criterion of micro-enterprises in Indonesia is that businesses with the highest net worth are IDR 50,000,000 with maximum sales proceeds of IDR 300,000,000. The criterion of small businesses in Indonesia is to have a net worth of more than IDR. 50,000,000 to IDR. $500,000,000$, and have sales of more than IDR. 300,000,000 to IDR. 2,500,000. 000, Criteria for medium-sized businesses in Indonesia are businesses that have a net worth of more than IDR. 500,000,000 up to 10,000,000,000 and have annual sales of more than IDR. 2,500,000,000 to IDR. 50,000,000-., (outside land and buildings in all categories) (Government of the Republic of Indonesia, 2008). 


\section{Research Method}

This research was conducted as an introduction to find out the public perceptions of MSMEs on the use of Fintech. This research was exploratory research. Exploratory research is basic research that aims to obtain description, information, and data about things that are not yet known. Exploratory research is carried out if the researcher has not obtained the initial data so that he has no picture at all about what will be studied. Exploratory research does not require certain hypotheses or theories, but prepares several questions as a guide to obtain primary data in the form of description, information, as the initial data needed (Leedy and Ormrod, 2005).

Descriptive analysis method was used in this study to find out how perceptions of economic actors (MSMEs) in getting loans and using payment transactions using Fintech. Sources of data from this study were primary data, by conducting direct research in the form of distributing questionnaires. The population in this study were MSMEs players in Medan, whose exact number was unknown. The sample design used was non-probability with sampling techniques using accidental sampling, and 126 samples of micro, small and medium enterprises (MSMEs) in Medan were obtained.

\section{a. Result}

Based on the result of the distributed questionnaires, the characteristic of samples is as below:

Table 1. Characteristics of Respondents

\begin{tabular}{lrl}
\hline Time & Participants & Percentage \\
\hline Gender & 42 & $66.7 \%$ \\
Male & 42 & $33.3 \%$ \\
Female & & \\
\hline Age & 54 & $42.9 \%$ \\
$<25$ years old & 34 & $27 \%$ \\
25-35 years old & 12 & $9.5 \%$ \\
36-45 years old & 24 & $19 \%$ \\
46-55 years old & 2 & $1.6 \%$ \\
$\quad>55$ years old & & \\
\hline Education & 2 & $1.6 \%$ \\
Elementary school & 4 & $3.2 \%$ \\
Junior & 54 & $42.9 \%$ \\
School High & 4 & $3.2 \%$ \\
Senior & 62 & $49.2 \%$ \\
School High & & \\
Diploma Degree & & \\
Bachelor Degree & & \\
\hline Business Fields & 30 & $23.8 \%$ \\
Grocery store & 20 & $15.9 \%$ \\
Culinary & 32 & $25.4 \%$ \\
Services & 2 & $1.6 \%$ \\
Farm & 42 & $33.3 \%$ \\
Other fields & 46 & $60.3 \%$ \\
\hline Monthly Income & & \\
$\leq$ IDR10.000.000, - & & \\
\hline & &
\end{tabular}




\begin{tabular}{lrl}
\hline \multicolumn{1}{l}{ Time } & Participants & Percentage \\
\hline \multicolumn{1}{l}{ IDR11.000.000, - to } & 22 & $17.5 \%$ \\
IDR25,000,000, - & 12 & $9.5 \%$ \\
IDR26.000.000, - to & 2 & $1.6 \%$ \\
IDR35.000.000, - & & \\
IDR36.000.000, - to & 14 & $11.1 \%$ \\
IDR50,000,000, - & & \\
IDR50.000.000, - & 76 & $60.3 \%$ \\
\hline Business Classification & 32 & $25.4 \%$ \\
$\quad$ Micro business & 18 & $14.3 \%$ \\
$\quad$ Small business & & \\
$\quad$ Middle business &
\end{tabular}

Based on the characteristics of the respondents, the largest respondents were those aged approximately 25 years with the average level of education for bachelor degrees and senior high schools. Based on the average income per month, $60.3 \%$ of respondents have income below IDR10,000,000. - each month. So that based on business classification, the largest respondents came from the micro business classification.

Below is a part of questions asked to the respondents to find out their perceptions regarding to banking and Fintech used.

Table 2. Comparison of community perceptions of banking products and Fintech products

\begin{tabular}{lcccc}
\hline \multirow{2}{*}{} & \multicolumn{2}{c}{ Banking } & \multicolumn{2}{c}{ Fintech } \\
\cline { 2 - 5 } & Yes & No & Yes & No \\
\hline Know about existence of & $100 \%$ & - & $44,4 \%$ & $55,6 \%$ \\
\hline Know the services provided by & $68,3 \%$ & $31,7 \%$ & $38,1 \%$ & $61,9 \%$ \\
\hline $\begin{array}{l}\text { Never use or apply for a Business } \\
\text { Credit to }\end{array}$ & $44,4 \%$ & $55,6 \%$ & $11,1 \%$ & $88,9 \%$ \\
\hline Using Payment Transactions with & $77,8 \%$ & $22,2 \%$ & $36,5 \%$ & $63,5 \%$ \\
\hline
\end{tabular}

Based on the questionnaire that had been collected, it was illustrated how the public perception of the existence of Fintech which had a role in payment transactions and business credit, the role which had been fulfilled by banks. Of the total respondents who were $100 \%$ aware of banking, only $44.4 \%$ knew the existence of Fintech. $63.3 \%$ knew the services provided by banks, $44.4 \%$ used or applied for business loans in banks, and $77 \%$ used payment transactions through banks.

Meanwhile, only $38.1 \%$ of respondents knew what services were provided by Fintech, $61.9 \%$ of the other respondents did not know about the services provided by Fintech. $36.5 \%$ of respondents had used Fintech in their payment transactions, and only $11.1 \%$ of respondents had used or applied for business loans using Fintech.

Below is a part of questions that was asked to the respondents to find out their needs and decisions about banking and Fintech products used.

Table 3. Introduction to Needs and Decisions to choose

\begin{tabular}{lcc}
\hline & Fintech & Banking \\
\hline Choose the needs of business credit & $46 \%$ & $54 \%$ \\
\hline Use of Payment Transactions & $15,90 \%$ & $84,10 \%$ \\
\hline
\end{tabular}




\begin{tabular}{lcc}
\hline Satisfaction with business credit services & $46 \%$ & $54 \%$ \\
\hline Satisfaction with payment transaction services & $39,70 \%$ & $60,30 \%$ \\
\hline Will provide recommendations on the use of services in business loans & $27 \%$ & $73 \%$ \\
\hline $\begin{array}{l}\text { Will provide recommendations on the use of services in payment } \\
\text { transactions }\end{array}$ & $33 \%$ & $66,70 \%$ \\
\hline Ease of credit procedures & $52,40 \%$ & $47,60 \%$ \\
\hline
\end{tabular}

Based on respondents who had known the existence and services of Fintech, respondents from MSMEs Medan were more likely to choose Banking for their business credit needs, namely $54 \%$. And Fintech as a payment transaction was only used by $15.9 \%$ of respondents, while $84.1 \%$ still chose banking in payment transactions.

Satisfaction with business credit services and payment transactions was still dominated by banks. In fact, respondents suggested using banking in business credit or payment transactions. Respondents who still recommended using banks for credit services were $73 \%$ while $66.7 \%$ for payment transactions. Nonetheless, there were $52.4 \%$ of respondents acknowledging that Fintech had more convenience on credit procedures.

\section{b. Discussion}

The largest respondents in this study were business people under the age of 25 years with undergraduate and high school education levels. At this age and level of education, generally they were used to using technology in their daily lives. The use of a smartphone or internet access had almost become a very ordinary thing. However, this study showed that respondents who were familiar with technology did not necessarily make them knowledgeable about financial technology.

As many as $54 \%$ of respondents who had backgrounds in MSMEs in Medan preferred to use banking products and services to fulfill their business credit needs. In payment transactions, only $15.9 \%$ of MSMEs in Medan used Fintech, the remaining $84.1 \%$ still chose banking services. Generally, the respondents' reasons to prefer to use banking in payment transactions and credit services were due to lack of socialization and understanding. This was in line with previous research observed the factors which influenced consumer acceptance of Fintech products and services in Malaysia. This study found that respondents would be more receptive to Fintech products and services when they already had had adequate knowledge of usability, convenience, advantages, potential risks and costs to be charged from the Fintech product or service (Jin, Seong and Khin, 2019); (Kim, Mirusmonov and Lee, 2010).

The reasons for security and trust also seemed to be the basic reasons for their lack of willingness to use Fintech. This research was in line with the research conducted by Taylor (2016) who reviewed the potential benefits and risks of payment instruments using mobile payment. The study observed that there was considerable potential risk in the use of Fintech so that the principle of consumer prudence was very important in using mobile payments (Taylor, 2016). Trust and security are the most important things in influencing the decision to use financial technology (Shin, 2009); (Au and Kauffman, 2008).

This research finding was quite a contradiction with the projections made by Bank Indonesia, which predicted that Indonesia's credit growth in 2023 would be contributed more by digital financing through Fintech. Bank Indonesia was also optimistic that this year Fintech's financing would be able to improve total lending in Indonesia (Kontan, 2018a). Based on business classification, $60 \%$ of respondents came from the micro-business 
classification, with average monthly income below IDR 10,000,000, -. Micro business actors were usually novice business actors, it was possible that this group was a group that still desperately needed capital and business development. This could be seen in the findings of the Financial Services Authority, namely that as of June 2018, there had been IDR 7.64 trillion in loan flows channeled from various Fintech lending providers. This meant that if $70 \%$ of the funds were absorbed by the retail sector, around IDR 5.35 trillion of funds from the Fintech company would flow to the micro-business classification (Kontan, 2018b). However, the national conditions were different from the findings in this study, so it could be concluded that there were possible gaps in socialization for MSMEs actors in the regions, especially in Medan.

Other study before has also been carried out in Malaysia to see the awareness and perception of Malaysian Small Medium Enterprises and start-ups on the existence of alternatives financing channels such as Peer-to-Peer lending and crowdfunding in supporting the growth and expansion of their business, this result showed that as alternative financing instruments, the level of awareness of most respondents is still insufficient on Peer-to-Peer lending and crowdfunding. Most of the perception results, a majority of Malaysian Small Medium Enterprises and start-ups have a slightly positive response or perception to the development of FinTech (Ghazali, N. H., \& Yasuoka, 2018).

\section{Conclusion}

The research conducted on 126 MSMEs actors in Medan illustrated that the public was still not too familiar with the financial technology and its services. Public were still more comfortable, and more confident in using credit services and financial transactions using banking services compared to technology financial services. The reasons for security and trust seemed to be the basic reasons for the lack of willingness of business people to fulfill financial needs based on technology. In addition, another reason that can be concluded was that the socialization provided to increase public knowledge of Fintech's presence in Indonesia was still very little, and this still needed further research.

In addition to the issue of trust and security, the development of existing technology and its facilities had not been fully utilized by Medanese people, especially Micro, Small and Medium Enterprises (MSMEs) actors in marketing their products and expanding their business.

This study suggests that there is a need and opportunity to raise awareness among Micro Small and Medium Enterprises by authorized government related body.

\section{References}

[1] Alimirruchi, W. and Kiswara, E. (2017) 'Analyzing Operational And Financial Performance On The Financial Technology (Fintech) Firm(Case Study On Samsung Pay)'.

[2] Asosiasi Penyelenggara Jasa Internet Indonesia (2016) 'Saatnya jadi Pokok Perhatian Pemerintah dan Industri', Buletin Asosiasi Penyelenggara Jasa Internet Indonesia, November.

[3] Au, Y. A. and Kauffman, R. J. (2008) 'The economics of mobile payments: Understanding stakeholder issues for an emerging financial technology application', Electronic Commerce Research and Applications, 7(2), pp. 141-164. doi: 10.1016/j.elerap.2006.12.004.

[4] Bank Indonesia (2016) Teknologi Finansial. Available at: 
https://www.bi.go.id/id/sistem-pembayaran/fintech/Contents/default.aspx (Accessed: 2 February 2018).

[5] Barquin, S. and Shrikhande, D. (2018) 'Asia's digital banking race: Giving customers what they want', (April), pp. 15-16, 18-19.

[6] Chishti, S. and Barberis, J. (2016) The FinTech Book. Great Britain: Tj. International Ltd,.Finansialku (2018) Apa itu FinTech Indonesia?, finansialku.com.

[7] Frame, W. S. and White, L. J. (2002) 'Empirical Studies of Financial Innovation: Lots of Talk, Little Action?', Ssrn, 42(1), pp. 116-144. doi: 10.2139/ssrn.325800.

[8] Freedman, R. S. (2006) Introduction to Financial Technology. London: Elsivier Academic Press Publication.

[9] Ghazali, N. H., \& Yasuoka, T. (2018) 'Awareness and Perception Analysis of Small Medium Enterprise and Start-up Towards FinTech Instruments-Crowdfunding and Peer-to-Peer Lending in Malaysia', International Journal of Finance and Banking Research, 4(1), pp. 13-24. doi: 10.11648/j.ijfbr.20180401.12.

[10] Government of the Republic of Indonesia (2008) 'Undang-Undang Republik Indonesia No. 20 Tahun 2008'. Indonesia. Available at: www.bi.go.id.

[11] Gunawan, A. and Koto, M. (2017) 'Analysis on factors influencing students financial literacy', Proceedings of AICS-Social Sciences, 7, pp. 289-295.

[12] Jin, C. C., Seong, L. C. and Khin, A. A. (2019) 'Factors Affecting the Consumer Acceptance towards Fintech Products and Services in Malaysia', International Journal of Asian Social Science, 9(1), pp. 59-65. doi: 10.18488/journal.1.2019.91.59.65.

[13] Kim, C., Mirusmonov, M. and Lee, I. (2010) 'An empirical examination of factors influencing the intention to use mobile payment', Computers in Human Behavior. Elsevier Ltd, 26(3), pp. 310-322. doi: 10.1016/j.chb.2009.10.013.

[14] Kontan (2018a) 'Pembiayaan dari Fintech bisa menyumbang 15\% dari seluruh kredit', kontan.co.id, 14 September. Available at: https://businessinsight.kontan.co.id/news/pembiayaan-dari-fintech-bisa-menyumbang15-dari-seluruh-kredit.

[15] Kontan (2018b) 'Pengamat: Mudah diakses, mayoritas dana fintech mengalir ke sektor mikro', kontan.co.id, 12 September. Available at: https://keuangan.kontan.co.id/news/pengamat-mudah-diakses-mayoritas-dana-fintechmengalir-ke-sektor-mikro.

[16] Koto, M. and Pulungan, D. R. (2017) 'The Financial Literacy of Students and investment Decision in The Indonesia Stock Exchange', Proceedings of AICS-Social Sciences, 7, pp. 305-3011.

[17] Leedy, P. . and Ormrod, J. . (2005) Planning and Design Research. Edisi 8. Ohio: Pearson Merrill Prentice Hall.

[18] Martowardojo, A. D. . (2016) 'Launching Bank Indonesia Fintech Office', (November), pp. 1-10.

[19] Rahardjo, B. (2017) 'Fintech: Layanan Baru, Ancaman Baru?', ekonomi.kompas.com. Available https://ekonomi.kompas.com/read/2017/01/17/163319426/.fintech.layanan.baru.ancam an.baru.

[20] Shin, D. H. (2009) 'Towards an understanding of the consumer acceptance of mobile wallet', Computers in Human Behavior. Elsevier Ltd, 25(6), pp. 1343-1354. doi: 10.1016/j.chb.2009.06.001.

[21] Soediro, R. (2018) Fintech Menurut Bank Indonesia: Kenali Jenis dan Manfaatnya, Investree.id. 
[22] Taylor, E. (2016) 'Mobile payment technologies in retail: a review of potential benefits and risks', International Journal of Retail \& Distribution Management, 44(22). doi: https://doi.org/10.1108/IJRDM-05-2015-0065. 